\title{
HOW DID TURKEY'S EU EXPORTS AFFECTED BY THE 2008 FINANCIAL CRISIS?
}

\author{
Assist. Dr. Yasin Kerem GÜMÜŞ* \\ Teksin Buğra BAĞCI**
}

\begin{abstract}
:
In this study it is aimed to examine the effects of financial crisis on Turkey's exports to the EU at the time of financial crisis in 2008. For this purpose the financial crisis has been compared within the 5year period before and after the crisis. The effects of the crisis on Turkey's trade volume is examined using econometric models. According to the results, before the financial crisis period (2003-2007) Turkey's exports increased in the motor vehicles sub-sectors; but sub sectors of meat and meat products, the textile and fertilizer wasn't provided a sufficient level of development. On the other hand, after the financial crisis period (2008-2013) sub-sectors of meat and meat products, the printing industry showed improvement; but motor vehicles, iron and steel financial crisis experienced decline. In the analysis of the results, the period before the financial crisis experienced growth in both exports and imports of Turkey's foreign trade. The increase in the share of the EU's trade before the crisis made a positive effects on the relations between Turkey and the EU. The financial crisis affected Turkey' exports to the EU in a negative way as a result of weakened the EU and axial dislocation in the trade relations.
\end{abstract}

Keywords: Customs Union, the 2008 Financial Crisis, Export, Turkey, EU

Jel Code: C51, C22, F3, G01

\footnotetext{
*Sakarya University, Faculty of Management, International Trade Department, Sakarya, ykgumus@sakarya.edu.tr

** Sakarya University, SBE, International Trade Department, Sakarya, teksinbugra@sakarya.edu.tr

Yrd.Doç.Dr., Cumhuriyet Üniversitesi, dilek58sahinhotmail.com.

Date of submission: 05.12.2016

Date of acceptance: 07.04.2017
} 


\section{INTRODUCTION}

In this study, the effects of the 2008 financial crisis on Turkey's trade with the EU were analyzed through models created by export figures between 2003 and 2013. The main purpose of the study is to determine the effects of the crisis on the export volume of Turkey to the EU.

In the first part of this study, previous studies about the effects of the Customs Union (CU) on Turkey were evaluated. In the second part, the commercial relations of the member countries of the Customs Union with Turkey are presented by taking into account the period between 2003 and 2013, namely the five years before and after the crisis. In the last section, the Augmented DickeyFuller (ADF) test results were generated by looking at autocorrelation to create time series and eliminate error terms. In the direction of this information, the positive and negative effects of the variables are taken into account for both the regression and in between themselves. The conclusion is based on the findings of the regression in relation to general trends in exports.

Data used in the study were formed by statistics from the Turkish Statistical Institute (TURKSTAT) and the Central Bank of the Republic of Turkey (CBRT). Monthly values were used when generating data sets. In this study, econometric analysis methods were used by using EViews 8.0 program. Structural tests were also applied to test the accuracy of the regression generated. In addition, CUSUM square test was applied to regression to see the effect of CU on net exports of Turkey after the crisis.

\section{THE IMPACT OF THE CUSTOMS UNION ON TURKEY}

Many studies have been carried out on the effects of the Customs Union on Turkey. Within these studies, Tonus (2007) stated that the Customs Union agreement between Turkey and the EU would facilitate trade and that Turkey's industrial products would directly affect productivity and production positively by creating competition in foreign countries. However, Morgül (2000) stated that the static and dynamic effects of the Customs Union will have adverse effects on the trade of Turkey. The static effects that are mentioned in that study are the effects of CU on the formation and diversion in Turkey while the dynamic effects are mentioned as effects such as increasing competition, technological development and capital mobility. In the study of 2012, Hatipler indicated Turkey's exports grew at an increasing rate of imports between 2000 and 2008, meaning that Turkey's exports to the EU increased faster than imports after the CU agreement. Accordingly, we can say that Turkey has increased its ability to compete against EU countries. By examining the sectoral dimensions of the Customs Union effects; Yenilmez ve Kılıç (2014) state that CU has an effect in the direction of increment of the drug industry export while Özer and Özçelik (2009) argue that 
production will increase in agricultural products and textiles but that the increase in prices due to demand will cause a contraction, but that full integration will lead to an increase in welfare. Apart from this, the fact that Filiztekin (2003), in relation to the contraction, also mentioned a trade creative effect as well as trade deflector effect after the period of CU can explain both the cause of the increase and the reason of the contraction.

Some of the studies before and after CU are as follows; Harrison, Rutherford and Tarr (1993) examined Turkish foreign trade before the CU and examined the situation after the CU in the 1997 article. They stated that the effect of Turkish foreign trade would be insufficient to increase the welfare in the post-CU period. In addition, Mercenier and Yeldan (1997) concluded that CU is inadequate to increase the country's well-being. Besides, we can find the effects of CU on our foreign trade in the most descriptive manner in TÜSİAD 2014 Evaluation Report. According to this report; since Turkey is not compatible with the EU in some sectors, it is treated as a third world country, which partially obstructs the operation of CU. On the other hand, it has also been analyzed that the share of services with the EU in the last 15 years has increased steadily.

It has been seen that in the literature of economics, researchers have applied many tests by creating many models. Aydın, Çıplak and Yücel (2004) studied Turkey's export and import demand by establishing two separate models, long and short period between 1987-1.quartile-2003-fourth quarters. Another research was carried out by Khan (1974) model. In this model, export-import demand functions of 15 different countries are created and analyzed together with Turkey. However, although Khan estimates these functions by the OLS method concludes that the prices in developing countries are influential on exports and imports, and found that the Marshall-Lerner condition is met (Akgündüz, 2015). Finally, Bahmani-Oskooee (1986) created export and import models for 7 different countries. As a result, they stated that the terms of trade are more interacting than the prices in the market rather than the effect of exchange rate.

\section{THE EFFECTS OF THE CUSTOMS UNION ON TURKEY'S FOREIGN TRADE BETWEEN 2003-2013}

Import and export volume figures of the Customs Union in the period of 2003-2013 in Turkey are shown in Figure I below. 


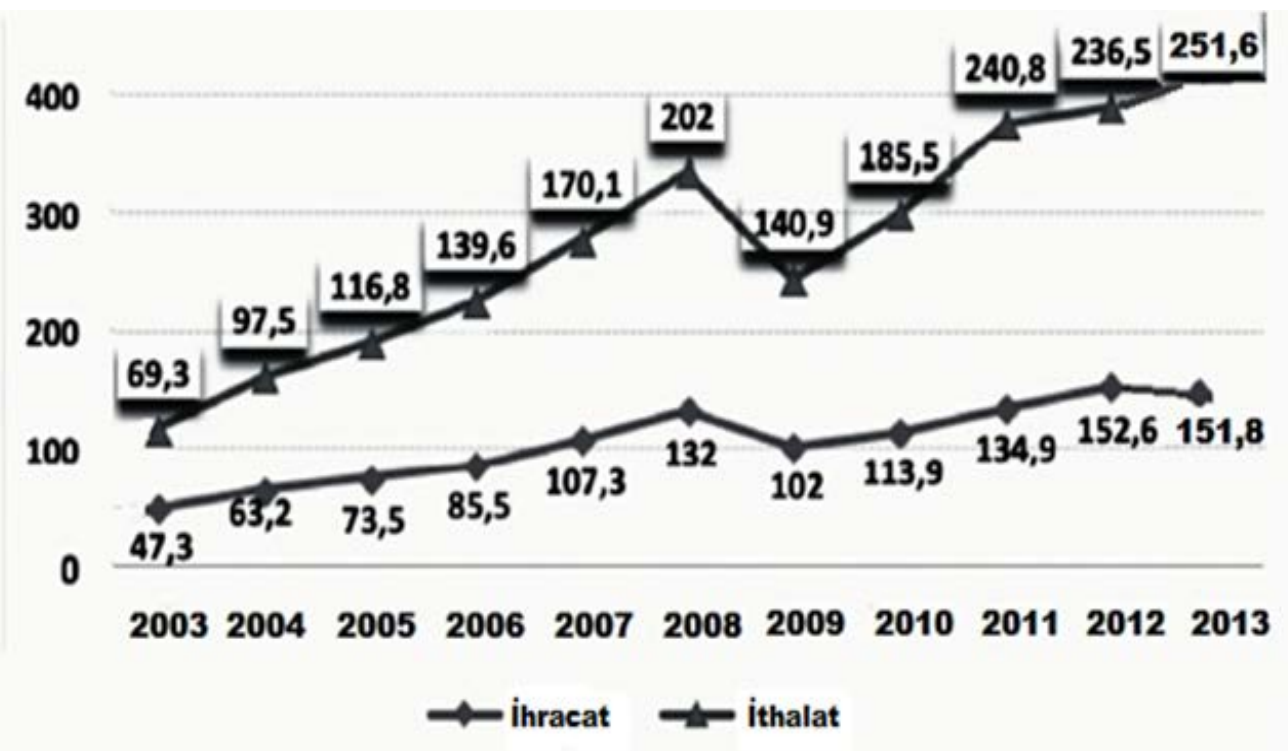

Figure I. Import and Export Volume of Turkey, (2003-2013)

As seen in figure I, the rate of increase in imports and exports of Turkey since 2003 continued until the end of 2008. However, as of the third and fourth quarters of 2008, foreign trade figures have fallen. The primary reason for this is the fact that the global crisis that financial institutions are facing has a negative impact on Turkey and that the domestic market is kept alive instead of imported products. In short, slowing economic activity has directly affected foreign trade. The exports and imports figures, which began to rise again by the 2009-2010 period, reached 403.4 billion dollars of foreign trade volume in 2013. However, this increase in the volume of foreign trade brought an increase in the foreign trade deficit with itself. 
Table I. Foreign Trade- Proportion of Export/Import According to Years, (\%, Annual)

\begin{tabular}{|c|c|}
\hline YEARS & Export/Import (\%) \\
\hline 2003 & 68,1 \\
\hline 2004 & 64,8 \\
\hline 2005 & 62,9 \\
\hline 2006 & 61,3 \\
\hline 2007 & 63,1 \\
\hline 2008 & 65,4 \\
\hline 2009 & 72,5 \\
\hline 2010 & 61,4 \\
\hline 2011 & 56 \\
\hline 2012 & 64,5 \\
\hline 2013 & 60,3 \\
\hline
\end{tabular}

Import coverage rate of exports; is the ratio of the total financial value of the products that a country sells abroad to the total financial value of the products that it receives from abroad. When this rate shrinks, it has a direct impact on the prosperity of a country. In addition, this rate shows us how much of the foreign currency required for imports is covered by the foreign exchange obtained in the export, and how much should be paid in other ways (Eğilmez, 2014). Table I shows the export and import coverage rates of Turkey between 2003 and 2013. According to Table I, the coverage rate, which was $68.1 \%$ in 2003, has been steadily decreasing until 2007 with the enactment of regulations and audits following the 2001 crisis and reached $61.3 \%$ at the end of 2006. However, balances were broken with the eruption of the 2008 global crisis between 2007 and 2009, and the crisis affected foreign exchange on behalf of Turkey, which resulted in an increase in export imports. In 2009, the rate rose to $72.5 \%$, reaching its lowest level in 2011 at 56\% and at the end of 2013 it was 60.3\%.

\section{III.I. The Effects of the Customs Union Before the 2008 Crisis on Foreign Trade in Turkey}

The Customs Union has been extremely positive from 2001-2002, when Turkey entered a period of restructuring, to the 2008 global crisis. Commercial agreements with EU countries, tax and legal regulations imposed by Turkey have a large share in foreign trade development. 
Table II. Turkey's Foreign Trade and the Share of the EU, (2003-2007)

\begin{tabular}{|l|l|l|l|l|l|l|l|}
\hline \multirow{2}{*}{ YEAR } & \multicolumn{2}{|c|}{$\begin{array}{c}\text { Turkey's Foreign Trade (Thousand } \\
\text { Dollars) }\end{array}$} & \multicolumn{2}{c|}{ EU(28) Foreign Trade (Thousand Dollars) } \\
\cline { 2 - 8 } & \multirow{2}{*}{ Export } & Import & TOTAL & Export & Import & TOTAL & $\begin{array}{l}\text { Share } \\
(\%)\end{array}$ \\
\hline $\mathbf{2 0 0 3}$ & 47.252 .836 & 69.339 .692 & $\mathbf{1 1 6 . 5 9 2 . 5 2 8}$ & 27.479 .360 & 35.156 .836 & $\mathbf{6 2 . 6 3 6 . 1 9 5}$ & 0,53 \\
\hline $\mathbf{2 0 0 4}$ & 63.167 .153 & 97.539 .766 & $\mathbf{1 6 0 . 7 0 6 . 9 1 9}$ & 36.698 .919 & 48.130 .900 & $\mathbf{8 4 . 8 2 9 . 8 1 9}$ & 0,52 \\
\hline $\mathbf{2 0 0 5}$ & 73.476 .408 & 116.774 .151 & $\mathbf{1 9 0 . 2 5 0 . 5 5 9}$ & 41.532 .953 & 52.781 .362 & $\mathbf{9 4 . 3 1 4 . 3 1 5}$ & 0,49 \\
\hline $\mathbf{2 0 0 6}$ & 85.534 .676 & 139.576 .174 & $\mathbf{2 2 5} \mathbf{1 1 0} \mathbf{8 5 0}$ & 48148628 & 59.447 .587 & $\mathbf{1 0 7 . 5 9 6 . 2 1 5}$ & 0,47 \\
\hline $\mathbf{2 0 0 7}$ & 107.271 .750 & 170.062 .715 & $\mathbf{2 7 7 ~ 3 3 4 ~ 4 6 4}$ & 60754022 & 68.472 .309 & $\mathbf{1 2 9 . 2 2 6 . 3 3 1}$ & 0,46 \\
\hline
\end{tabular}

Table II shows Turkey's import and export trade with EU countries between 2003 and 2007. We can also see from the table that the EU is the most important foreign trade partner after the participation of Turkey to the CU. Having an average 50\% share in our foreign trade between 20032007, we see that the EU gives the biggest support to trade in the 2008 global crisis (Table IV). In 2003, Turkey's foreign trade was \$ 116 billion, but in 2007 it doubled from 2003 to 277 billion dollars. It is a fact that a strong economy like EU has a 50\% share in foreign trade of Turkey means that it will be beneficial for the development of the country and we have seen that, in the 2008 crisis, we will be economically affected in a more profound way in case of an economic crisis in EU. 
Table III. Turkey's Sectoral Dimension Foreign Trade Development, (2003-2007)

\begin{tabular}{|c|c|c|c|c|c|c|c|c|c|c|}
\hline YILLAR & 20 & 03 & 20 & & 200 & & 20 & 06 & 20 & 07 \\
\hline FASILLAR & ITHALAT & IHRACAT & ITHALAT & IHRACAT & ITHALAT & IHRACAT & ITHALAT & IHRACAT & ITHALAT & IHRACAT \\
\hline $\begin{array}{l}\text { Mineral yakıtlar, mineral } \\
\text { yağlar }\end{array}$ & 11575069 & 980133 & 14407288 & 1429186 & 21255586 & 2641145 & 28859098 & 3567425 & 33883135 & 5147932 \\
\hline Aastikler ve mamülleri & 3235625 & 926036 & 4763094 & 1323732 & 5795589 & 1722148 & 6918411 & 2214266 & 8688044 & 2822051 \\
\hline Demir ve çelik & 4747844 & 2969012 & 8031522 & 5359512 & 9457831 & 4973475 & 11525251 & 6273353 & 16182379 & 8372260 \\
\hline $\begin{array}{l}\text { Kazanlar, makinalar, mekanik } \\
\text { cihazlar, aksam ve parçaları }\end{array}$ & 10293923 & 2992983 & 13456962 & 4125934 & 16400315 & 5246419 & 18998763 & 6516726 & 22570359 & 8781251 \\
\hline Pamuk & 1641454 & 997278 & 1982197 & 1219991 & 2079291 & 1179569 & 2090189 & 1338306 & 2829539 & 1611317 \\
\hline $\begin{array}{l}\text { Motorlu kara taşıtları, aksam, } \\
\text { parça, aksesuarı }\end{array}$ & 5383395 & 5272017 & 10237024 & 8288799 & 10552792 & 9566435 & 11408441 & 11886092 & 12397295 & 15903675 \\
\hline Eczacilik ürünleri & 2019378 & 179444 & 2710136 & 248216 & 2849272 & 282796 & 3035614 & 312613 & 3523655 & 357778 \\
\hline Eler ve yenilen sakatat & 181 & 18720 & 277 & 22487 & $2 \pi$ & 36217 & 86 & 29468 & 97 & 46518 \\
\hline $\begin{array}{l}\text { Ayakkabılar,getrler,todukl } \\
\text { ar vb eşya ve aks amı }\end{array}$ & 191058 & 183788 & 303284 & 204917 & 412786 & 215793 & 514970 & 237069 & 569929 & 316740 \\
\hline $\begin{array}{l}\text { Me şrubat, alk ollü içkiler ve } \\
\text { sirke }\end{array}$ & 18716 & 70429 & 48982 & 113696 & 5212 & 148627 & 74179 & 147177 & 92569 & 174557 \\
\hline Gübreler & 394233 & 20371 & 640339 & 39178 & 755397 & 37755 & 784415 & 37558 & 997460 & 84346 \\
\hline $\begin{array}{l}\text { Bas ili kitap,gazete, res im } \\
\text { vb bas ki sanayi mamulu,el } \\
\text { yazmalari }\end{array}$ & 92871 & 30945 & 119050 & 37212 & 137963 & 49499 & 131590 & 53956 & 153560 & 74789 \\
\hline
\end{tabular}

The Customs Union has had a positive impact on the growth of some sectors by ensuring the development of Turkey's import and export capacity. Table III shows that the customs union's fastest development in total exports of Turkey is in the sub sectors of 'motor vehicles, parts, accessories'. Apart from this, the increase in boilers, machinery, mechanical parts, plastics and products, iron and steel sub-sectors is striking. But meat and meat products, fertilizers, textile sub-sectors did not develop as much as export competence. When we look at import in more detail; it is seen that the sectors which do not show increase in exports show an increase of imported products. These developments coincide with the predictions that Turkey is one of the important production centers in the automotive, white goods, machinery and electronics sectors in middle and high technology level in the Ninth Five-Year Development Plan (DPT, 2006). 


\section{III.II. Effects of the Customs Union after the 2008 Crisis on Foreign Trade in Turkey}

The relationship of Turkey's import and export volume with the EU countries between 2008 and 2013 is shown in Table IV.

Table IV. Turkey's Foreign Trade and EU's Share, (2008-2013)

\begin{tabular}{|c|c|c|c|c|c|c|c|}
\hline \multirow{2}{*}{ YEAR } & \multicolumn{3}{|c|}{$\begin{array}{c}\text { Turkey's Foreign Trade (Thousand } \\
\text { Dollars) }\end{array}$} & \multicolumn{4}{|c|}{ EU(28) Foreign Trade (Thousand Dollars) } \\
\hline & Export & Import & TOTAL & Export & Import & TOTAL & Export \\
\hline 2008 & 132.027 .196 & 201.963 .574 & 333.990.770 & 63.719 .097 & 74.513 .444 & 138.232.541 & 0,41 \\
\hline 2009 & 102.142 .613 & 140.928 .421 & 243.071.034 & 47.228 .119 & 56.616 .302 & 103.844 .421 & 0,42 \\
\hline 2010 & 113.883 .219 & 185.544 .332 & 299.427.551 & 52.934 .452 & 72.391 .053 & 125.325.505 & 0,41 \\
\hline 2011 & 134.906 .869 & 240.841 .676 & 375.748.545 & 62.589 .257 & 91.439 .406 & 154.028 .664 & 0,40 \\
\hline 2012 & 152.461 .737 & 236.545 .141 & 389.006.877 & 59.398.377 & 87.657 .462 & 147.055 .839 & 0,37 \\
\hline 2013 & 151.802 .637 & 251.661 .250 & 403.463 .887 & 63.039 .810 & 92.457.992 & 155.497 .803 & 0,38 \\
\hline
\end{tabular}

Table IV shows the share of EU in import and export volume of Turkey between 2008-2013. According to this, total foreign trade in Turkey increased in 2008 compared to 2007, but the share of the EU decreased by $41 \%$ compared to the previous year. The reason for this is that with the beginning of the global crisis, Europe's trade has weakened and the purchasing power has fallen. In 2009, Turkey was affected by the crisis and lost about one third of its foreign trade. However, the share of the EU remained at the same level despite the contraction in volume. We see that with the declining EU share between 2010 and 2013, Turkey is heading to different regions and trade areas because Europe is losing its power. The EU share, which was $41 \%$ in 2010, has reached $38 \%$ by the end of 2013 . From 2003 to 2013, it is observed that the share of EU-originated foreign trade volume has gradually decreased in recent years. 
Table V. Turkey's Sectoral Dimension Foreign Trade Development, (2008-2013)

\begin{tabular}{|c|c|c|c|c|c|c|c|c|c|c|c|c|}
\hline \multirow{2}{*}{ FASILLAR YILAR } & \multicolumn{2}{|c|}{2008} & \multicolumn{2}{|c|}{2009} & \multicolumn{2}{|c|}{2010} & \multicolumn{2}{|c|}{2011} & \multicolumn{2}{|c|}{2012} & \multicolumn{2}{|c|}{2013} \\
\hline & ITHALAT & IHRACAT & ITHALAT & IHRACAT & ITHALAT & İHRACAT & ITHALAT & IHRACAT & ITHALAT & IHRACAT & ITHALAT & İHRACAT \\
\hline $\begin{array}{l}\text { Mineral yakıtlar, mineral } \\
\text { yağlar }\end{array}$ & 48281193 & 7531776 & 29905305 & 3921300 & 38497229 & 4469479 & 54117539 & 6539030 & 60117407 & 7708169 & 55917155 & 6724654 \\
\hline Plastikler ve mamülleri & 9385517 & 3563148 & 6944490 & 3093759 & 9730432 & 3716596 & 12578501 & 4580258 & 12505398 & 5012899 & 13881017 & 5608724 \\
\hline Demir ve çelik & 23160241 & 14946358 & 11351640 & 7641010 & 16120796 & 8740067 & 20424235 & 11225329 & 19642041 & 11332482 & 18690888 & 9918794 \\
\hline $\begin{array}{l}\text { Kazanlar, makinalar, mekanik } \\
\text { cihazlar, aksam ve parçalan }\end{array}$ & 22539348 & 10258590 & 17131962 & 8132787 & 21266830 & 9413411 & 27110683 & 11560990 & 26315986 & 11999300 & 30156654 & 12989247 \\
\hline Pamuk & 2331906 & 1633650 & 2098707 & 1278472 & 3385753 & 1449154 & 3608860 & 1922073 & 2377563 & 1785532 & 2989181 & 1928176 \\
\hline $\begin{array}{l}\text { Motorlu kara taşıtları, a ksam, } \\
\text { parça, akses uarı }\end{array}$ & 12789717 & 18326711 & 8975864 & 12251734 & 13419356 & 13812677 & 17184080 & 15803438 & 14514293 & 15148114 & 16808266 & 17000250 \\
\hline Eczaclık ürünleri & 4360581 & 421134 & 4080491 & 429061 & 4410051 & 558172 & 4697445 & 566797 & 3995652 & 661783 & 4151045 & 754085 \\
\hline Etler ve yenilen sakatat & 906 & 89124 & 1600 & 154896 & 250174 & 208012 & 513600 & 390255 & 97179 & 532489 & 25275 & 614698 \\
\hline $\begin{array}{l}\text { Ayakkabilar,getrler,tozlukl } \\
\text { ar vbeşya ve aksamı }\end{array}$ & 672917 & 344890 & 539468 & 289473 & 659674 & 395624 & 871464 & 441247 & 863682 & 545923 & 992947 & 723219 \\
\hline $\begin{array}{l}\text { Meşrubat, a lkollü içkile r ve } \\
\text { sirke }\end{array}$ & 111785 & 194316 & 128229 & 180748 & 138969 & 229518 & 212984 & 258721 & 213852 & 285734 & 265435 & 295391 \\
\hline Gübreler & 1481756 & 217321 & 1057507 & 83679 & 1016777 & 205484 & 1374434 & 200598 & 1382438 & 147397 & 1492105 & 98501 \\
\hline \begin{tabular}{|l|} 
Basili kitap,gazete,re sim \\
vb bas ki sanayi mam ulu,el \\
yazmalari
\end{tabular} & 169591 & 82212 & 127847 & 84745 & 138097 & 84248 & 170942 & 89759 & 166170 & 88778 & 176832 & 94698 \\
\hline
\end{tabular}

If we look at the attitudes of the sectors in terms of exports after the global crisis; The sectors most affected by the 2008 global crisis are mineral fuels, mineral oils, iron and steel, motor vehicles, components and parts sub-sectors. On the other hand, the sectors which are not affected by the crisis but in contrast the ones increased are; pharmaceutical products, meat and meat products, printed books, newspapers and printing industry products. When we look at sectoral values for imports, the global crisis has seen a decline in the sub-sectors of mineral fuels, mineral oils, iron and steel, boilers, machinery, mechanical appliances and motor vehicles. However, the increase continued over the following years and resulted over the exports.

In general, if we make the assessment of the Customs Union over Turkey between 2003 and 2013, Turkey has seen an average of 50\% of its imports and exports in the EU countries between 2003 and 2008, with the effect of this crisis, which was experienced in Europe with the 2008 crisis, the decline in terms of foreign trade. As a result, the positive effects created by the Customs Union have decreased. The inability of Turkey to sell the goods which it has produced to Europe caused new trade gates to open, which in turn transformed it into trading with African countries under the Arab Spring name between 2008-2011. During this period, the import deficit declined and the current account deficit was reduced, but with the recovery of the EU over time, the import volume increased and the current account deficit continued to increase. In short, we can say that the customs union has 
achieved a steady increase in Turkey's trade with the EU countries at the same rates until the crisis period. Even though this situation did not seem to lead to a loss in the commercial market of Turkey at that time, negative effects after the global crisis took place in the Turkish economy.

\section{AN EMPIRICAL STUDY ON THE EFFECTS OF THE CUSTOMS UNION ON EXPORT VOLUME OF TURKEY BEFORE AND AFTER THE 2008 CRISIS (2003-2013)}

In this section, the research model will be developed first. Then, in the process of estimating the model, the method, the universe and the sampling, the collection of the data, the analysis and interpretation of the data will be given respectively. In the research model, a regression will be created that primarily includes macroeconomic variables that are effective in Turkey's exports. While the dependent variable of this regression is exports, the independent variables are imports, inflation, exchange rate, policy rate and Foreign Capital. In the created model, stationarity and unit root tests, cointegration and autocorrelation corrections are done in time series. The study includes analyzing Turkey's trade performance between the EU Customs Union in 1996 and the trade process between 2003 and 2013 and the effects of variables affecting foreign trade on Turkey's exports. The variables determining the exports, namely Imports, Inflation, Exchange Rate, Policy Rate and Foreign Equity variables are added to the model. Data used in the study are monthly time series covering the period 2003-2013. The data used are obtained from the web sites of the CBRT, the Turkish Statistical Institute (TURKSTAT) and the Ministry of Treasury's electronic data distribution system. Exports are expressed as variables of import (million \$), foreign capital variables (billion dollars), exchange rate change, policy interest rate and inflation (wholesale price index).

\section{IV.I. Analysis of Data and Regression Tests}

In this section, unit root tests analysis, general model expansion, cointegration and autocorrelation applications will be discussed by regression.

\section{IV.I.I. Analysis of Unit Root Tests}

Before estimating the variables, the figures should be plotted and then the stagnation of the variables will be examined using the Augmented Dickey-Fuller (ADF) test. Within the model; EXPORT: Exports, IMPORT: Import, POLITIKAFAIZ: Policy Interest Rate, DOVIZKURU: Exchange Rate, FDI: Foreign Capital, TEFE: Inflation. However, the logarithmic results are obtained by taking the first differences for each variable to be sufficient for describing the model. 

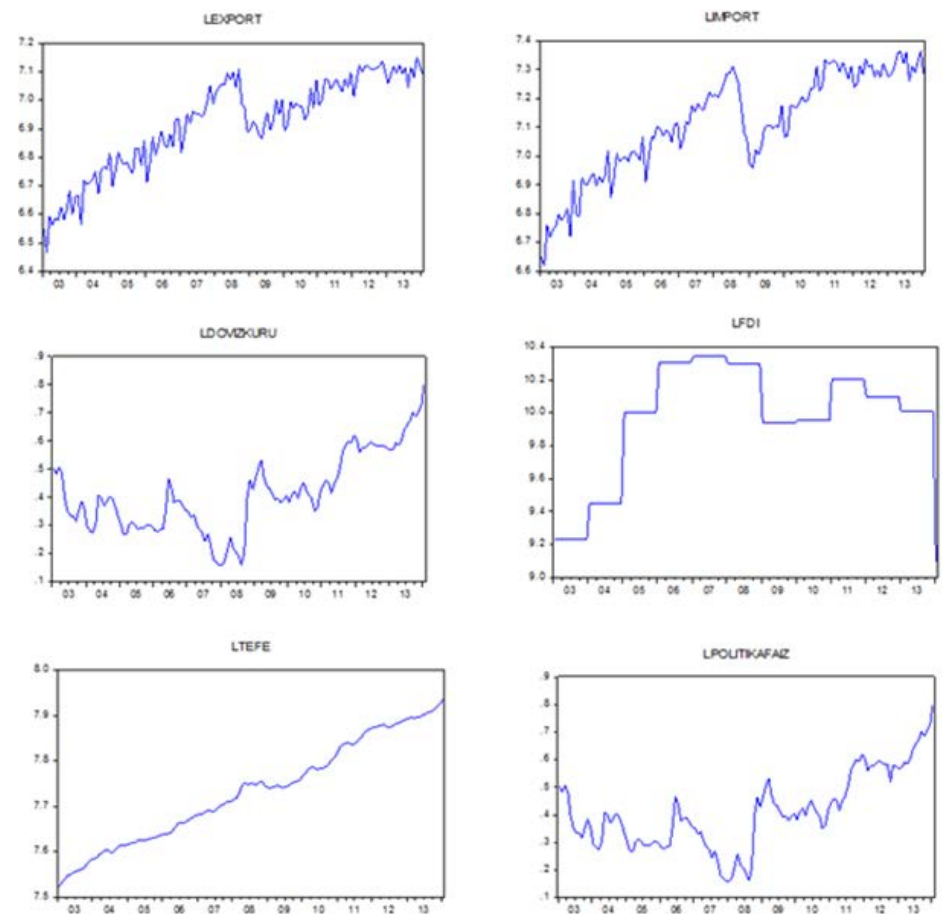

Figure II. Time Series Figures of Variables

When we examine the figures; we see that the LTEFE, LIMPORT and LEXPORT charts have a positive trend. In addition, LIMPORT and LEXPORT variables declined in early 2008 and began to increase towards the end of 2008. However, LDOVIZKURU and LPOLITIKAFAIZ variables have a positive trend even though they have cyclical fluctuations between 2003 and 2013. However, it is not possible to say the same for LFDI because the positive trend in 2003-2007 declined in the following years and showed a negative trend from the middle of 2010 to the end of 2013. According to these figures, we can say that there is no stagnation in this time series.

After interpreting the time series figures of the variables, the ADF tests; Export, import, foreign capital, exchange rate, policy interest rate and inflation were conducted to determine whether these variables are stationary. 
Table VI. ADF Unit Root Test Results (Level) ${ }^{\dagger}$

\begin{tabular}{|c|c|c|c|c|c|c|}
\hline \multirow[b]{2}{*}{ Variable } & \multicolumn{6}{|c|}{ ADF TEST } \\
\hline & Coefficient & $\begin{array}{l}\text { Std. } \\
\text { Error }\end{array}$ & $\begin{array}{l}A D F \\
t \text {-stat }\end{array}$ & Probability & $R$-squared & $\begin{array}{l}\text { Durbin-Watson } \\
\text { stat }\end{array}$ \\
\hline LEXPORT & -0.069751 & 0.02839 & -2.45692 & 0.0153 & 0.044374 & 2.874977 \\
\hline LIMPORT & -0.066356 & 0.025339 & -2.61871 & 0.0099 & 0.050108 & 2.685993 \\
\hline LPOLITIKAFAIZI & -0.005878 & 0.023589 & -0.24916 & 0.8036 & 0.000477 & 1.428032 \\
\hline LDOVIZKURU & -0.004222 & 0.022945 & -0.184 & 0.8543 & 0.00026 & 1.348044 \\
\hline LFDI & -0.042313 & 0.027376 & -1.54565 & 0.1246 & 0.018045 & 1.431452 \\
\hline LTEFE & -0.001231 & 0.003098 & -0.39737 & 0.6918 & 0.001213 & 1.157479 \\
\hline
\end{tabular}

According to the ADF t-stat values, only LIMPORT is stationary at the level and other variables are not stationary. However, the ADF test is not taken at this stage since we can see the 1.difference values in autocorrelation.

\section{IV.I.II. General Model}

In the study, it is aimed to see how the effects of macro variables such as imports, foreign capital, exchange rates, interest rates and inflation on exports. According to this; in the research model; Exports are dependent variable and import, foreign capital, exchange rate, policy interest rate and inflation are independent variables. Equation of model:

$$
Y=\alpha+\beta 1 \text { limport }+\beta 2 \text { ldovizkuru }+\beta 3 \text { ltefe }+\beta 4 \text { lfdi }+\beta 5 \text { lpolitikafaiz }+u t
$$

\section{LEXPORT = f (LIMPORT, LDOVISURE, LTTE, LFDI, LPOLITHICAFAIS)}

LEXPORT from the variables in the model, the meaning of the terms are: LIMPORT: Import (Million \$), LFDI: Foreign Capital (Million \$), LDOVIZKURU: Exchange Rate, LPOLITIKAFAIZ: Interest Rate (\%), LTEFE: Inflation (wholesale price index, \%) : ut: the error term and L: logarithm.

\footnotetext{
${ }^{\dagger}$ ADF test critical values; $1 \%$ level; -3.480425 , at the 5\% level; -2.883408 and at the level of $10 \%$; -2.578510 .
} 


\section{IV.I.III. Cointegration Analysis}

The cointegration analysis is the analysis of parameters to determine whether the parameters which are static at the level but can be stable in the long run. Then, the stability of the unit root test error term is examined. According to this, it can be decided whether long-term equilibrium is established or not.

$\mathrm{H}_{0}$ : No cointegration for all units.

$\mathrm{H}_{1}$ : Some units have cointegration.

Analysis of the cointegration of variables according to the formation of hypotheses has been carried out. A new long-run equilibrium model was established within the statistical results of the model in Table VII.

Table VII. Long Term Balance Model

\begin{tabular}{|c|c|c|c|c|}
\hline \multicolumn{5}{|c|}{$\begin{array}{l}\text { Dependent Variable: LEXPORT } \\
\text { Method: Least Squares } \\
\text { Sample: } 2003 \text { M01 2014M01 } \\
\text { Included observations: } 133\end{array}$} \\
\hline Variable & Coefficient & Std. Error & t-Statistic & Prob. \\
\hline LIMPORT & 0.560368 & 0.058376 & 9.599341 & 0 \\
\hline LFDI & 0.024237 & 0.013384 & 1.810972 & 0.0725 \\
\hline LTEFE & 0.595012 & 0.108202 & 5.499062 & \\
\hline LDOVIZKURU & 0.503298 & 0.513 & 0.981087 & 0.3284 \\
\hline LPOLITIKAFAIZ & -0.627149 & 0.511045 & -1.22719 & 0.222 \\
\hline $\mathrm{C}$ & -1.860837 & 0.474276 & -3.92353 & 0.0001 \\
\hline R-squared & 0.961514 & \multicolumn{2}{|c|}{ Mean dependent var } & 6.918121 \\
\hline Adjusted R-squared & 0.959999 & \multicolumn{2}{|c|}{ S.D. dependent var } & 0.165369 \\
\hline S.E. of regression & 0.033074 & \multicolumn{2}{|c|}{ Akaike info criterion } & -3.936047 \\
\hline Sum squared resid & 0.138928 & \multicolumn{2}{|c|}{ Schwarz criterion } & -3.805655 \\
\hline Log likelihood & 267.7471 & \multicolumn{2}{|c|}{ Hannan-Quinn criter. } & -3.883061 \\
\hline F-statistic & 634.5775 & \multicolumn{2}{|c|}{ Durbin-Watson stat } & 1.427619 \\
\hline Prob(F-statistic) & 0 & & & \\
\hline
\end{tabular}

When we look at the model results, it is seen that variables are generally meaningful by looking at the t-statistic values. However, since the variables LDOVIZKURU and LPOLITIKAFAIZ are statistically insignificant, the long-term model is estimated again by subtracting these two variables from the model. 
Table VIII. New Long-Term Balance Model

\begin{tabular}{|l|l|l|r|r|}
\hline $\begin{array}{l}\text { Dependent Variable: LEXPORT } \\
\text { Method: Least Squares } \\
\text { Sample: 2003M01 2014M01 } \\
\text { Included observations: } 133\end{array}$ & & & & \\
\hline & Coefficient & Std. Error & t-Statistic & Prob. \\
\hline \hline Variable & 0.64267 & 0.051352 & 12.51503 & 0 \\
\hline LIMPORT & 0.036775 & 0.013067 & 2.814361 & 0.0057 \\
\hline LFDI & 0.360236 & 0.068389 & 5.267451 & 0 \\
\hline LTEFE & -0.806576 & 0.284832 & -2.83176 & 0.0054 \\
\hline C & 0.958562 & Mean dependent var & 6.918121 \\
\hline \hline R-squared & 0.957598 & S.D. dependent var & 0.165369 \\
\hline Adjusted R-squared & 0.034052 & Akaike info criterion & -3.892215 \\
\hline S.E. of regression & 0.149585 & Schwarz criterion & -3.805287 \\
\hline Sum squared resid & 262.8323 & Hannan-Quinn criter. & -3.856891 \\
\hline Log likelihood & 994.6866 & Durbin-Watson stat & 1.235161 \\
\hline F-statistic & 0 & & & \\
\hline Prob(F-statistic) & & & & \\
\hline
\end{tabular}

The reproduced long term model was found to be statistically significant and the unit root test (ADF) was applied to the error term (ut) of the long run parameters obtained.

Table IX. Error Term in Long Term Model ADF Test Result

\begin{tabular}{|} 
Critical Values of the Test \\
\begin{tabular}{|c|r|r|r|}
\hline & \multicolumn{3}{|c|}{ Test Kritik Değerleri } \\
\cline { 2 - 4 } ADF Test Stat. & $1 \%$ & $5 \%$ & $10 \%$ \\
\hline 3.155634 & -2.6522 & -1.954 & -1.6223 \\
\hline
\end{tabular}
\end{tabular}

As can be seen from Table IX, there is no unit root in the model according to ADF test result. If the error in the long-run model does not include the unit root, it indicates that this series is cointegrated.

\section{IV.I.IV. Autocorrelation Analysis}

If the stationarity of the variables is tested with the ADF and if we have to interpret by the SIC, the presence of autocorrelation is determined in Table VI and re-evaluation is required by entering the necessary delay values on it. In addition, in the reconstructed long-run model, the DurbinWatson value of 1.2351 in Table VIII indicates that autocorrelation is present. Accordingly, we need to perform autocorrelation analysis for the new long-term model. Because, in order to be able to see the accuracy of the regression, it should be applied by correcting autocorrelation. On the other hand, what delays are included in Annex 1 have also been analyzed. 


\begin{tabular}{|c|c|c|c|c|}
\hline \multicolumn{5}{|c|}{$\begin{array}{l}\text { Dependent Variable: LEXPORT } \\
\text { Method: Least Squares } \\
\text { Sample (adjusted): } 2003 \mathrm{M} 092014 \mathrm{MO} 1 \\
\text { Included observations: } 125 \text { after adjustments } \\
\text { Convergence achieved after } 16 \text { iterations } \\
\text { MA Backcast: } 2003 \mathrm{M} 012003 \mathrm{M} 08 \\
\end{array}$} \\
\hline Variable & Coefficient & Std. Error & t-Statistic & Prob. \\
\hline$\overline{C \mathrm{C}}$ & -0.305112 & 0.42581 & -0.71655 & 0.4751 \\
\hline LIMPORT & 0.762841 & 0.054043 & 14.11557 & 0 \\
\hline LFDI & -0.002363 & 0.01658 & -0.14255 & 0.8869 \\
\hline LTEFE & 0.235463 & 0.08284 & 2.842375 & 0.0053 \\
\hline $\operatorname{AR}(1)$ & 0.374392 & 0.085122 & 4.398307 & 0 \\
\hline $\operatorname{AR}(8)$ & -0.217349 & 0.111637 & -1.94693 & 0.0539 \\
\hline $\mathrm{MA}(8)$ & 0.70208 & 0.086794 & 8.089024 & 0 \\
\hline R-squared & 0.960052 & \multicolumn{2}{|c|}{ Mean dependent var } & 6.940514 \\
\hline Adjusted R-squared & 0.958021 & \multicolumn{2}{|c|}{ S.D. dependent var } & 0.143464 \\
\hline S.E. of regression & 0.029394 & \multicolumn{2}{|c|}{ Akaike info criterion } & -4.161679 \\
\hline Sum squared resid & 0.101953 & \multicolumn{2}{|c|}{ Schwarz criterion } & -4.003293 \\
\hline Log likelihood & 267.1049 & \multicolumn{2}{|c|}{ Hannan-Quinn criter. } & -4.097335 \\
\hline F-statistic & 472.6429 & \multicolumn{2}{|c|}{ Durbin-Wats on stat } & 2.03257 \\
\hline Prob(F-statistic) & 0 & & & \\
\hline \multirow[t]{2}{*}{ Inverted AR Roots } & $.82+.31 i$ & $.82-.31 \mathrm{i}$ & $.36-.75 i$ & $.36+.75 i$ \\
\hline & $-.27-.76 i$ & $-.27+.76 \mathrm{i}$ & $-.72+.31 i$ & $-.72-.31 \mathrm{i}$ \\
\hline \multirow[t]{2}{*}{ Inverted MA Roots } & $.88+.37 i$ & $.88-.37 i$ & $.37-.88 \mathrm{i}$ & $.37+.88 i$ \\
\hline & $-.37+.88 \mathrm{i}$ & $-.37-.88 \mathrm{i}$ & $-.88-.37 i$ & $-.88+.37 i$ \\
\hline
\end{tabular}

The autocorrelation in the regressions can be seen depending on whether Durbin-Watson value is close to "2" or not. According to the obtained results, if we compare the values of the new long model before autocorrelation with those after autocorrection; The Durbin-Watson value was increased from 1.2351 to 2.0325, and the autocorrelation was removed from this value by decreasing the Durbin-Watson value to 2.0325, even though R-squared was high in both models, as the significance of the model was interpreted to be zero (F-statistic). Correlogram lengths are specified in Annex-2.

\section{IV.I.V. CUSUM Square Test}

At the end of the econometric analysis, the CUSUM square test, which is the cumulative sum of the squares of the error terms, was applied to test the instability of the variables in the model. The CUSUM square test is more sensitive than other structural fracture tests and is based on the calculation of consecutive residues. The confidence limits are determined by drawing a figure of the model errors in a confidence interval specified by this test. If it is outside the limits of confidence, it is decided that there is a structural change, and if it does not, it is decided that there is no structural change. CUSUM square test can also be used to determine the period of structural break. It is possible to see the effects of the 2008 global crisis according to the result of the model. 


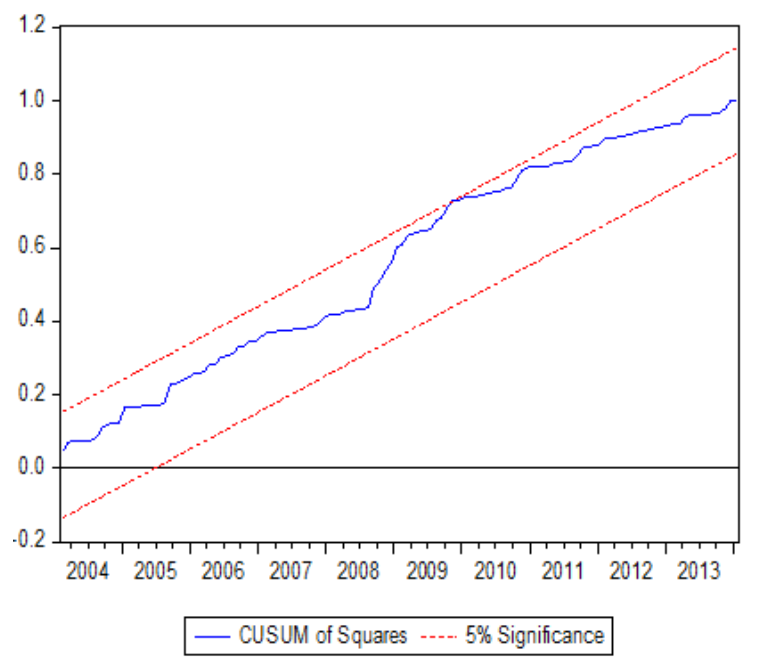

Figure III. CUSUM Square Structural Fracture Test (2003: 1-2014: 1)

According to figure 3; there is no deviation from the specified confidence interval. It is only possible to say that these variables are not unstable because they do not exceed the confidence interval of $5 \%$, even though they are close to the confidence intervals in June-July 2009. According to the model results obtained after eliminating autocorrelation; a 1\% increase in exports could lead to an increase of $0.7628 \%$ in imports, a decrease in foreign capital inflows of $0.0023 \%$ and an increase in inflation of $0.2354 \%$. The result of the CUSUM square test is an indication that the variables move together. Again, after autocorrelation, the value of $\mathrm{R} 2=0.96$ reveals the export explanation power of the model independent variables. As an example of independent variables explaining exports, 1 unit increase in imports can make 1 unit effect on exports; 1 unit increase in foreign capital has resulted in 1 unit decrease in exports.

\section{CONCLUSIONS AND RECOMMENDATIONS}

We will arrive at an econometric analysis of the effects of Turkey's macro exports on exports; the development of Turkey's exports is primarily dependent to the participation of the EU Customs Union, the increase in imports, the closure of the current account deficit resulting from the importation of foreign capital, and the exchange rate relationship with inflation.

As seen after the 2008 financial crisis, the effects of the Customs Union diminished, exports declined and imports decreased. The Customs Union seems to encourage direct exports as well as encourage exports. We can say that the positive and negative effects of the EU Customs Union will have an impact as structural breaks in the period take place. In the analysis, it is observed that the increase in foreign trade in the period between 2003 and 2007 has increased both in export and import, and that the share of trade within the EU has increased with time by increasing the need for the 
Customs Union. In the context of the global crisis between 2008 and 2013, the EU has lost power and the foreign trade has shifted to different countries, by this way the ineffectiveness of the EU Customs Union has also emerged.

In the econometric analysis carried out in the study, it was concluded that exports were directly affected by other variables. As a result, if Turkey could increase its export capacity in its own economy and develop its foreign trade by selling technology-intensive products in developed markets, the sensitivity of Turkey to the EU Customs Union will be further reduced. In this sense, it can be predicted that Turkey can have a real growth both in terms of economic and financial and social welfare, and that its external commitment can be reduced to a certain extent, thereby lowering its current deficit. 


\section{REFERENCES}

Akgündüz, M. 2015. Gümrük Birliği Öncesi ve Sonrasında Türkiye Ille AB Ülkeleri Arasındaki İthalat-İhracat İlişkileri: Ekonometrik Bir Analiz, Paper presented at VIII. Economics Students Congress, İzmir.

Aydın, M.F., U, Çıplak \& Yücel M.E. 2004 'Export Supply and Import Demand Models for the Turkish Economy', TCMB Research Department paper, No: 04/09.

Bahmani-Oskooee, M. 1985. Devaluation and the J-Curve: Some Evidence from Ldcs, the Review of Economics and Statistics, 67 (3): 500-504.

DPT, 2006. 9. Development Plan Specialization Commission Report, pp.87, Ankara.

Eğilmez, M. 2013 'Kendime Yazılar' www.mahfiegilmez.com/2013/12/TurkiyeninDisticareti. Html, (access 21.04.2015)

Filiztekin. A. 2003. Avrupa Birliği İle Gümrük Birliğinin Türkiye İmalat Sanayi Üzerindeki Etkileri',', Paper presented at Kalder 12. National Quality Congress, İstanbul.

Hamour, E.A. 1999. Impacts of Increased Exposure to International Competition: The Case of the Turkish Textile Industry, the Journal of Economic Coorperation, 20 (4): 35-71.

Harrıson, G.W., Rutherford, TF \& Tarr T.G. 1993. Trade Reform in the Partially Liberalized Economy of Turkey, the World Bank Economic Review, 7 (2):191-217.

Khan, M.S. 1974. Import and Export Demand In Developing Countries, IMF Staff Papers, 21:678693.

Mercenier, J., \& Yeldan, E. 1997. On Turkey’s Trade Policy: Is a Custom Union with Europe Enough? European Economic Review, No 41: 871-880.

Morgil, O. 2000. The Impact of Trade Liberalızatıon: Turkey's Experience with the Customs Union, Hacettepe University School of Management Journal, 18 (2): 189-195.

Ocak, B. S. 2009. Türk Sanayii Ve Özel Sektör Rekabet Olanaklarına Genel Bakış, IMKB Journal, $1(1): 1-12$.

Özer, O.O., \& Özçelik, A. 2009. Tarım Ürünlerinin Gümrük Birliği Kapsamına Alınması Durumunda Pamuk Ve Tekstil Sektörü Üzerinde Yaratacağı Etkiler: Bir Genel Denge Analizi, Agricultural Economics Journal, 15 (2): 1-9. 
Tonus Ö. 2008. 'Openness and İndustrialization in Turkey after the Customs Union, Anadolu University MPRA Paper No.7121: 195.

Ulusoy, A., 2002. Türkiye Ayakkabı Sanayi ve Dış Ticareti, Foreign Trade Journal, 26: 85100.

Yenilmez F., \& Kılıç, E. 2014. Gümrük Birliği Ve Serbest Ticaret Anlaşmalarının Türkiye Illaç Sektörü Ithalatına Etkisi, Paper Presented at International Conference in Economics, Prague. 
APPENDICES

Table A.I Autocorrelation in the New Long-Term Model

Sample: 2003M01 2014M01

Included observations: 125

\begin{tabular}{|c|c|c|c|c|c|c|}
\hline Autocorrelation & Partial Correlation & & $\mathrm{AC}$ & PAC & Q-Stat & Prob \\
\hline$.\left.\right|^{*} \quad \mid$ & $. .^{*} \quad \mid$ & 1 & 0.136 & 0.136 & 2.3607 & 0.124 \\
\hline $.1 . \quad \mid$ &.$|. \quad|$ & 2 & 0.026 & 0.008 & 2.4499 & 0.294 \\
\hline.$|. \quad|$ &.$|. \quad|$ & 3 & 0.042 & 0.038 & 2.6819 & 0.443 \\
\hline.$|. \quad|$ &.$|. \quad|$ & 4 & -0.005 & -0.017 & 2.6856 & 0.612 \\
\hline.$|. \quad|$ &.$|. \quad|$ & 5 & 0.045 & 0.048 & 2.9514 & 0.707 \\
\hline$*|. \quad|$ & $*|. \quad|$ & 6 & -0.102 & -0.118 & 4.3433 & 0.630 \\
\hline$*|. \quad|$ & $*|. \quad|$ & 7 & -0.127 & -0.100 & 6.5031 & 0.482 \\
\hline.$|. \quad|$ & $. .^{*} \quad \mid$ & 8 & 0.045 & 0.077 & 6.7732 & 0.561 \\
\hline.$|. \quad|$ &.$|. \quad|$ & 9 & -0.058 & -0.064 & 7.2375 & 0.612 \\
\hline.$|\quad|$ &.$|. \quad|$ & 10 & 0.032 & 0.054 & 7.3830 & 0.689 \\
\hline $.1 . \quad \mid$ &.$|. \quad|$ & 11 & -0.014 & -0.022 & 7.4100 & 0.765 \\
\hline.$|. \quad|$ &. $\mid . \quad 1$ & 12 & -0.040 & -0.031 & 7.6393 & 0.813 \\
\hline.$|. \quad|$ &.$|. \quad|$ & 13 & 0.003 & -0.023 & 7.6405 & 0.866 \\
\hline.$|. \quad|$ &.$|. \quad|$ & 14 & -0.038 & -0.029 & 7.8464 & 0.897 \\
\hline $.1 . \quad \mid$ &.$|. \quad|$ & 15 & 0.025 & 0.038 & 7.9355 & 0.926 \\
\hline$*|. \quad|$ & $*|. \quad|$ & 16 & -0.146 & -0.173 & 11.044 & 0.807 \\
\hline$*|. \quad|$ &.$|. \quad|$ & 17 & -0.113 & -0.051 & 12.926 & 0.741 \\
\hline
\end{tabular}




\begin{tabular}{|c|c|c|c|c|c|c|}
\hline. $\mid$ &. $\mid$ & 18 & 0.054 & 0.064 & 13.355 & 0.770 \\
\hline $.1^{*}$ &..$^{*}$ & 19 & 0.096 & 0.103 & 14.735 & 0.739 \\
\hline. &. $\mid$ & 20 & -0.009 & -0.049 & 14.746 & 0.791 \\
\hline. &..$^{*}$ & 21 & 0.060 & 0.076 & 15.293 & 0.808 \\
\hline. &. $\mid$ & 22 & 0.025 & -0.004 & 15.392 & 0.845 \\
\hline.$\left.\right|^{*}$ &. $\mid$ & 23 & 0.085 & 0.014 & 16.513 & 0.832 \\
\hline. &. $\mid$ & 24 & -0.033 & -0.051 & 16.680 & 0.862 \\
\hline
\end{tabular}

Table A.II. Corrected Autocorrelation in the New Long-Term Model

Sample: 2003M01 2014M01

Included observations: 125

Autocorrelation Partial Correlation $\quad$ AC $\quad$ PAC Q-Stat Prob

\begin{tabular}{|c|c|c|c|c|c|c|c|c|}
\hline.$^{*}$ & 1 &.$\left.\right|^{*}$ & | & 1 & 0.136 & 0.136 & 2.3607 & 0.124 \\
\hline. $\mid$ & | &. $\mid$. & | & 2 & 0.026 & 0.008 & 2.4499 & 0.294 \\
\hline. $\mid$ & 1 &. $\mid$ & | & 3 & 0.042 & 0.038 & 2.6819 & 0.443 \\
\hline. $\mid$ & | &. $\mid$. & | & 4 & -0.005 & -0.017 & 72.6856 & 0.612 \\
\hline. & | &. $\mid$ & | & 5 & 0.045 & 0.048 & 2.9514 & 0.707 \\
\hline & 1 & $* \mid$ & $\mid$ & 6 & -0.102 & -0.118 & 4.3433 & 0.630 \\
\hline & | & $* \mid$ & | & 7 & -0.127 & -0.100 & 6.5031 & 0.482 \\
\hline. & $\mid$ &.$\left.\right|^{*}$ & | & 8 & 0.045 & 0.077 & 6.7732 & 0.561 \\
\hline .1. & 1 & .1. & | & 9 & -0.058 & -0.064 & 7.2375 & 0.612 \\
\hline. & 1 & .1 & | & 10 & 0.032 & 0.054 & 7.3830 & 0.689 \\
\hline
\end{tabular}


Y. K. Gümüş-T. B. Bağcı/ IREM, 4 (4), 2016, 39-60.

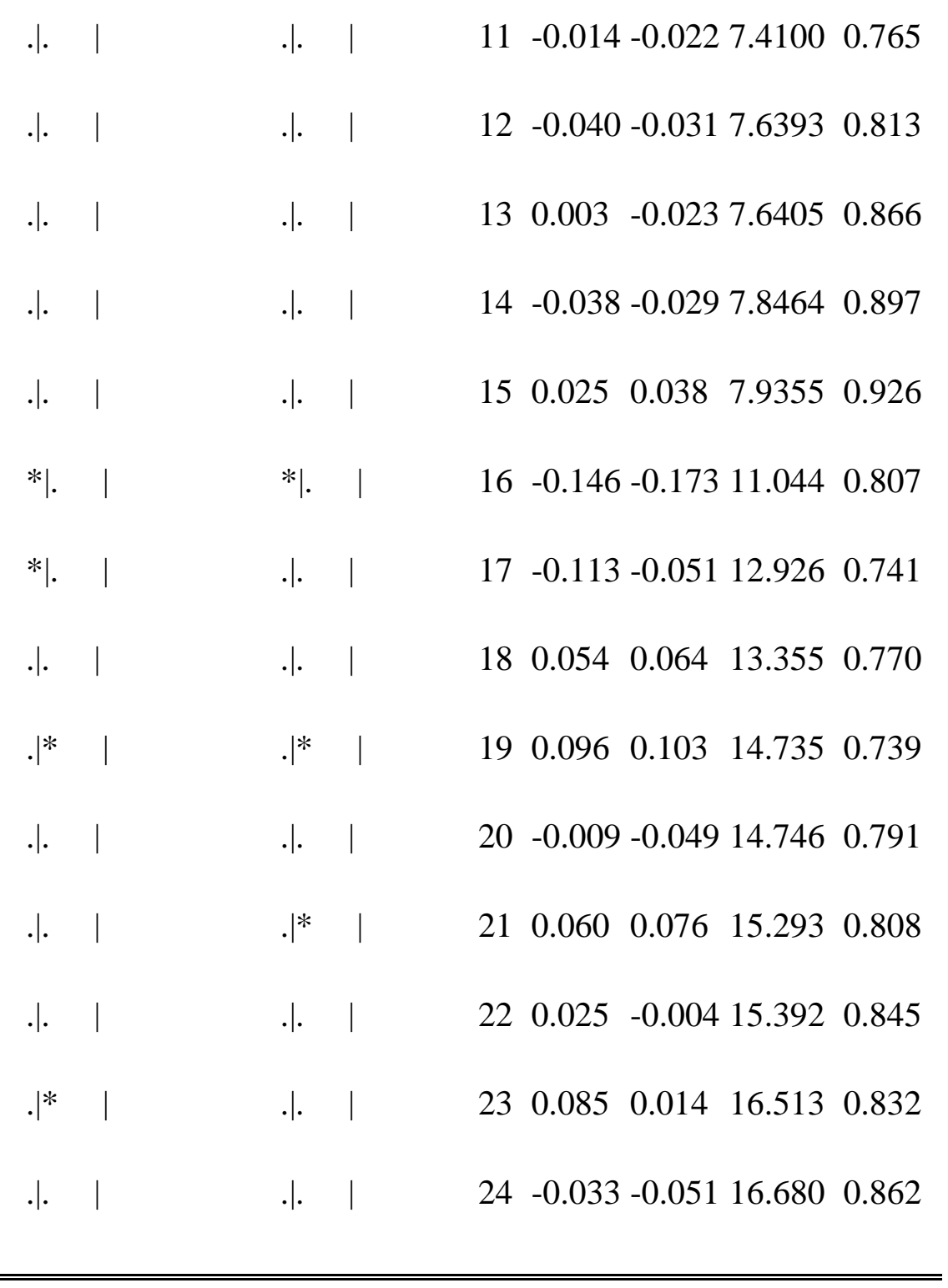

